\title{
Risk of anorexia and bulimia nervosa and its associated factors in undergraduate students
}

\author{
Risco de anorexia e bulimia nervosa \\ e seus fatores associados em \\ estudantes de graduação
}

Gustavo Alfonso DÍAZ MUÑOZ1 iD 0000-0002-9216-7873

\section{A B S T R A C T}

\section{Objective}

To quantify the prevalence and related factors to the risk of anorexia and bulimia nervosa in undergraduate students at a private university in Bogotá, Colombia.

\section{Methods}

A cross-sectional study, which evaluated the frequency of food consumption, physical activity (International Physical Activity Questionnaire, short form), the risk of anorexia and bulimia nervosa (Sick, Control, One, Fat, and Food questionnaire) and demographic variables. The statistical analysis used a multivariate logistic regression model, where the outcome was the yes/no risk of anorexia or bulimia nervosa.

\section{Results}

A total of 1,545 university students participated. The average age was 19.2 years (+/-2.5), $65.7 \%$ were women, and $63.9 \%$ came from Bogotá. The risk of anorexia and bulimia nervosa was $27.6 \%$. In the logistic regression, the risk was associated with female sex (OR 1.6 CI95\% 1.2 to 2.1), daily consumption of cereals (OR 0.7 CI95\% 0.6 to 0.9 ), daily fat consumption (OR $1.5 \mathrm{Cl}$ (95\% 1.1 to 2.1), eat light products (OR $1.8 \mathrm{CI} 5 \% 1.1$ to 2.9), consume protein supplements (OR $0.4 \mathrm{Cl}$ (95\% 0.2 to 0.8), being in disagreement with physical activity for fun (OR $1.8 \mathrm{CI}$ (95\% 1.1 to 3.1), and physical activity by appearance (OR 2.2 CI95\% 1.6 to 2.9 ).

\section{Conclusions}

The prevalence of risk to anorexia and bulimia nervosa in the study sample is high. The associated factors were the consumption of cereals, fat, light products, and protein supplements. Physical activity by appearance and disagreement 1 Universidad El Bosque, Instituto de Nutrición, Genética y Metabolismo, Facultad de Medicina. Av. Cra 9 131A-02, Bogotá, Colômbia.
E-mail: <diazgustavo@unbosque.edu.co>.

How to cite this article

Díaz Muñoz GA. Risk of anorexia and bulimia nervosa and its associated factors in undergraduate students. Rev Nutr. 2021;34:e200067. https://doi.org/10.1590/1678-9865202134e200067 
to do exercise by fun were associated with the risk of anorexia and bulimia nervosa. So it is recommended that universities implement awareness and education interventions to address this problem.

Keywords: Anorexia nervosa. Bulimia nervosa. Feeding and eating disorders. Universities.

\section{RE S U M O}

\section{Objetivo}

Quantificar a prevalência e os fatores relacionados ao risco de anorexia e bulimia nervosa em estudantes de graduação de uma universidade particular de Bogotá, Colômbia.

\section{Métodos}

Estudo transversal, que avaliou a frequência de consumo alimentar, atividade física (ferramenta (Questionário Internacional de Atividade Física, versão curta), risco de anorexia e bulimia nervosa (Questionário de doença, controle, um, gordura e comida) e variáveis demográficas. A análise estatística utilizou um modelo de regressão logística multivariada, em que o resultado foi o risco sim / não de anorexia ou bulimia nervosa.

\section{Resultados}

Participaram 1.545 estudantes universitários. A idade média era de 19,2 anos (+/- 2,5), 65,7\% eram mulheres e 63,9\% eram de Bogotá. O risco de anorexia e bulimia nervosa foi de $27,6 \%$. Na regressão logística, o risco foi associado ao sexo feminino (OR 1,6 IC95\% 1,2 a 2,1), consumo diário de cereais (OR 0,7 IC95\% 0,6 a 0,9), consumo diário de gordura (OR 1,5 IC95\% 1,1 a 2,1), comer produtos leves (OR 1,8 IC95\% 1, 1 a 2,9), consomem suplementos proteicos (OR 0,4 IC95\% 0,2 a 0,8), discordam de atividade física para se divertir (OR 1,8 IC95\% 1,1 a 3, 1) e atividade física pela aparência (OR 2,2 C195\% 1,6 a 2,9).

\section{Conclusão}

A prevalência de risco para anorexia e bulimia nervosa na amostra do estudo é alta. Os fatores associados foram o consumo de cereais, gorduras, produtos light e suplementos proteicos. A atividade física pela aparência e a discordância para fazer exercício pela diversão estiveram associadas ao risco de anorexia e bulimia nervosa. Portanto, é recomendado que as universidades implementem intervenções de conscientização e educação para resolver esse problema.

Palavras-chave: Anorexia nervosa. Bulimia nervosa. Transtornos da Alimentação e da Ingestão de Alimentos. Universidades.

\section{INTRODUCTION}

The risk of Anorexia or Bulimia Nervosa (ABN) increases in university students by the adolescentadult transition, academic stress, change of roles, and sociocultural environment pressure [1]. Also, due to technologies and cultural changes in university students, the risk of ABN is associated with other diseases such as health bone, stress and depression, cyber addiction, exercise addiction, and attention deficit disorder and hyperactivity [2-5].

The risk of $A B N$ in university students is different by countries, examples given: Arabia $20.4 \%$, USA 6.8\%, France 18.3\%-20.7\%, Malaysia 43.5\%, México 15\%, Spain 19.5\%-29.2\%, and India 34.1\%. This variability of the prevalence is due to cultural differences, but, is a call of attention to the high presence of these diseases in the university [2-10].

The prevalence of risk of $A B N$ in Colombian university students is unknown, but various risk behaviors are prevalent in some age groups studying at the university. The National Survey of Mental Health in Colombia describes the prevalence of any risk behaviors to anorexia or bulimia nervosa is $9 \%$ in the 1244-year group; in the same way, the National survey of nutrition in Colombia detail in the 13-29-year group that around $9.5 \%$ of them take any risk conduct to lose or maintain weight [11].

In universities, some papers detail risk behaviors to anorexia or bulimia nervosa. At a university in Medellin, $40 \%$ of the women were fanatics of light food and $52 \%$ are constantly experimenting with 
diets. The risk factors associated were female sex, high socioeconomic status, not perform physical activity, experiment with diets, and search for a way to lose weight; however, these findings cannot be extrapolated to all Colombian universities, due to cultural and programs differences in each university [12].

Therefore, identify the prevalence of risk of $A B N$ and its associated factors permit to make an epidemiology profile of the risk on the population, let the opportunity to develop prevention strategies, and build research projects in university students. In consequence, the aim was to estimate the prevalence of the risk of $\mathrm{ABN}$ and its associated factors in students at a private university in Bogota.

\section{METHO D S}

A cross-sectional study was performed in one private university in Bogota. The university was chosen due to the feasibility to do the research in that place. The survey was applied in August 2017, except in academic examination days. This research applied the Helsinki Declaration, the Word Health Association, the local principles of research in humans, and was approved by the bioethics committee; the participants gave written informed consent.

The entire population was 5,537 students in I to IV semester of bachelor degrees $(56.4 \%$ female; $19.9 \pm 3$ years; first semester $24.4 \%$; second semester $24.7 \%$; third semester $19.3 \%$; fourth semester $31.6 \%$ ). The sample size calculated was 359 (confidence level 95\%; maximum expected prevalence 50\%; accepted error $5 \%$ ); due to information of students was private, the probabilistic sampling was not possible. All population was convocated and sampling was by intention to participate. Students of I to IV semester were selected because they have established customs and assist regularly at the university. Exclusion criteria were interchange student, vegetarian, physical or mental disability, foreigners, or women in pregnancy or breastfeeding.

A virtual questionnaire was sent to students and each faculty provide 25 minutes in a classroom by semester to fill the questionnaire. Academics variables were faculty and semester; the source of information was the academic register office. The participants informed about sex (male/female), age in years, provenance region (Colombian regions), socioeconomic level ( 1 to $6 ; 1$ is low and 6 is high), civil status (single or with a couple), work (yes/no), a couple (yes/no), height, and weight.

The risk of $A B N$ was measured with the Sick, Control, One, Fat, and Food questionnaire (SCOFF); SCOFF is an acronym to the five characteristics of anorexia and bulimia nervosa. This tool is easy to fill, contains five interrogations, and has been validated in Colombian university students [13]. The university student had a risk of ABN if participant answered "yes" in two or more questions $[8,13]$.

The evaluation of eating habits included food times and daily consumption of food groups. Principal food times (breakfast, lunch, and dinner) and intermediate food times were measures. A food frequency questionnaire was performed to evaluate the daily consumption (yes/no answer) of twelve groups of food: cereals, vegetables, fruits, dairy products, meat-eggs-offal, legumes-grains-seeds, fats, sugar, carbonated beverages, packaged foods, coffee-tea-aromatic, light foods, and whole foods. The food frequency questionnaire was the same tool validated in the National survey of nutrition in Colombia [14].

The level of physical activity was measured by the International Physical Activity Questionnaire-short form (IPAQ-SF) [15]. This tool provided three levels of physical activity: low, medium, and high. Further, the scale of Motives for Physical Activity (MPAM-R) was applied, evaluating five motives (health, appearance, competition, social, and fun) and generated two levels of accord (yes/no) for each motive [16]. 
Frequency and percentage were used to describe categorical variables. Quantitative variables were described by mean, median, standard deviation, or interquartile range (according to normal distribution tested by Shapiro Wilk test). For each mean and percentage was reported confidence interval at 95\% (C195\%). The bivariate analysis employed the risk of ABN (yes/no). The comparison of categorical variables used Pearson's Chi-Square test or Exact Fisher test; the U-Mann-Whitney test was employed to compare quantitative variables. Significant was $p$-value $<0.05$.

Additionally, a logistic multivariate model was performed by forward steps. The dependent variable was yes/no risk of $A B N$. Independent variables entered in the model were those in bivariate analyses obtaining a p-value $<0.25$ and without collinearity (Spearman correlation coefficient test o theoretical approach). The explanatory power of the model or variability of the risk of anorexia and bulimia was assessed by Pseudo R2. The association estimator used was the OR with confidence interval of 95\% (C195\%). The statistical software was STATA 12 licensed for Universidad El Bosque.

\section{RE S U L T S}

A total of 1,545 university students participated, with an average age of $19.2+/-2.5$ years, $65.7 \%$ were women, and $63.9 \%$ of the students were from the city of Bogotá. The faculties with the greatest participation in the research were medicine (30.8\%), engineering $(17.1 \%)$, and education (10.4\%), while participation by academic semesters was similarly distributed (Table 1). More details of the characteristics of the sample can be found in a previous report [17]. The risk of ABN was observed in $27.6 \%$ of the participants and the risk behaviors were described in Figure 1.

Table 1. Characteristics of populations. Bogotá, Colombia, 2018.

\begin{tabular}{|c|c|c|c|c|c|c|}
\hline \multirow{3}{*}{ Variables } & \multirow{2}{*}{\multicolumn{2}{|c|}{$\frac{n=530}{34.3 \%(31.9-36.7)}$}} & \multirow{2}{*}{\multicolumn{2}{|c|}{$\frac{n=1,015}{65.7 \%(63.3-68.1)}$}} & \multirow{2}{*}{\multicolumn{2}{|c|}{$n=1,545$}} \\
\hline & & & & & & \\
\hline & $\%$ & $\mathrm{C} 195 \%$ & $\%$ & $\mathrm{Cl} 95 \%$ & $\%$ & $\mathrm{C} 195 \%$ \\
\hline \multicolumn{7}{|l|}{ Age } \\
\hline Mean \pm SD & \multicolumn{2}{|c|}{$19.5 \pm 2.6$} & \multicolumn{2}{|c|}{$19.1 \pm 2.5$} & \multicolumn{2}{|c|}{$19.2 \pm 2.5$} \\
\hline $\mathrm{C} 195 \%$ & \multicolumn{2}{|c|}{$19.3-19.7$} & \multicolumn{2}{|c|}{$18.9-19.2$} & \multicolumn{2}{|c|}{$19.1-19.3$} \\
\hline \multicolumn{7}{|l|}{ Age groups } \\
\hline $15-17$ years & 15.5 & $12.4-18.6$ & 21.3 & $18.8-23.8$ & 19.3 & $17.3-21.3$ \\
\hline $18-25$ years & 80.9 & $77.6-84.3$ & 76.7 & $74-79.3$ & 78.1 & $76.1-80.2$ \\
\hline $26-40$ years & 3.6 & $1.9-5.2$ & 2.1 & $1.2-2.9$ & 2.6 & $1.8-3.4$ \\
\hline \multicolumn{7}{|l|}{ Provenance region } \\
\hline Bogotá & 64.3 & $60.3-68.4$ & 63.7 & $60.8-66.7$ & 63.9 & $61.6-66.3$ \\
\hline Bogotá surroundings & 3.2 & $1.7-4.7$ & 2.1 & $1.2-2.9$ & 2.5 & $1.7-3.2$ \\
\hline Eastern & 11.9 & $9.1-14.6$ & 14.5 & $12.3-16.7$ & 13.6 & 11.9-15.3 \\
\hline Central & 8.3 & $5.9-10.7$ & 9.5 & $7.7-11.3$ & 9.1 & $7.6-10.5$ \\
\hline Atlantic & 4.9 & $3.1-6.7$ & 4.1 & $2.9-5.4$ & 4.4 & $3.4-5.4$ \\
\hline Pacific & 2.5 & $1.1-3.8$ & 2.0 & $1.1-2.8$ & 2.1 & $1.4-2.9$ \\
\hline Amazon-Orinoquia & 4.9 & $3.1-6.7$ & 4.1 & $2.9-5.4$ & 4.4 & $3.4-5.4$ \\
\hline \multicolumn{7}{|l|}{ Socioeconomic level } \\
\hline 1 & 1.9 & $0.7-3$ & 2.1 & $1.2-2.9$ & 2.0 & $1.3-2.7$ \\
\hline 2 & 11.9 & $9.1-14.6$ & 14.8 & $12.6-17.0$ & 13.8 & $12.1-15.5$ \\
\hline 3 & 34.5 & $30.5-38.6$ & 42.6 & $39.5-45.6$ & 39.8 & $37.4-42.3$ \\
\hline 4 & 33.4 & $29.4-37.4$ & 26.0 & 23.3-28.7 & 28.5 & 26.3-30.8 \\
\hline 5 & 13.0 & $10.1-15.9$ & 12.1 & 10.1-14.1 & 12.4 & $10.8-14.1$ \\
\hline 6 & 5.3 & $3.4-7.2$ & 2.5 & $1.5-3.4$ & 3.4 & $2.5-4.3$ \\
\hline
\end{tabular}


Table 1. Characteristics of populations. Bogotá, Colombia, 2018.

\begin{tabular}{|c|c|c|c|c|c|c|}
\hline \multirow{3}{*}{ Variables } & \multirow{2}{*}{\multicolumn{2}{|c|}{$\begin{array}{c}\mathrm{n}=530 \\
34.3 \%(31.9-36.7)\end{array}$}} & \multirow{2}{*}{\multicolumn{2}{|c|}{$\begin{array}{c}n=1,015 \\
65.7 \%(63.3-68.1)\end{array}$}} & \multirow{2}{*}{\multicolumn{2}{|c|}{$n=1,545$}} \\
\hline & & & & & & \\
\hline & $\%$ & $\mathrm{C} 195 \%$ & $\%$ & $\mathrm{C} 195 \%$ & $\%$ & $\mathrm{Cl} 195 \%$ \\
\hline \multicolumn{7}{|l|}{$\overline{\text { Civil status }}$} \\
\hline Single & 97.0 & $95.5-98.4$ & 94.7 & $93.3-96.1$ & 95.5 & $94.4-96.5$ \\
\hline With couple & 3.0 & $1.6-4.5$ & 5.3 & $3.9-6.7$ & 4.5 & $3.5-5.6$ \\
\hline Work, yes & 18.3 & $15.0-21.6$ & 10.9 & $9.0-12.9$ & 13.5 & $11.8-15.2$ \\
\hline Couple, yes & 35.3 & $31.2-39.4$ & 43.5 & $40.5-46.6$ & 40.7 & $38.3-43.2$ \\
\hline \multicolumn{7}{|l|}{ Faculty } \\
\hline Science & 7.7 & $5.5-10.0$ & 4.3 & $3.1-5.6$ & 5.5 & $4.3-6.7$ \\
\hline Economy & 7.7 & $5.5-10.0$ & 3.6 & $2.4-4.7$ & 4.8 & $3.7-5.9$ \\
\hline Politic & 3.6 & $2.0-5.2$ & 3.8 & $2.7-5.0$ & 3.7 & $2.8-4.7$ \\
\hline Creation & 9.1 & $6.6-11.5$ & 4.8 & $3.5-6.1$ & 6.3 & $5.0-7.5$ \\
\hline Education & 7.7 & $5.5-10.0$ & 12.2 & $10.2-14.2$ & 10.4 & $8.9-12.0$ \\
\hline Nursing & 4.0 & $2.3-5.6$ & 11.5 & $9.6-13.5$ & 8.8 & $7.4-10.3$ \\
\hline Engineering & 25.3 & $21.6-29.0$ & 12.5 & $10.5-14.6$ & 17.1 & 15.1-19.0 \\
\hline Medicine & 22.1 & $18.5-25.6$ & 35.3 & $32.3-38.2$ & 30.8 & 28.4-33.2 \\
\hline Odontology & 3.8 & $2.1-5.4$ & 7.2 & $5.6-8.8$ & 6.3 & $5.0-7.5$ \\
\hline Basic course & 9.1 & $6.6-11.5$ & 4.7 & $3.4-6.0$ & 6.3 & $5.0-7.5$ \\
\hline \multicolumn{7}{|l|}{ Semester } \\
\hline 1 & 30.4 & $26.3-34.4$ & 22.6 & $19.9-25.2$ & 25.3 & $23.0-27.5$ \\
\hline$\|$ & 26.8 & $22.9-30.7$ & 27.7 & $24.8-30.5$ & 27.3 & $25.0-29.6$ \\
\hline III & 19.4 & $16.0-22.9$ & 20.7 & $18.1-23.2$ & 20.2 & $18.2-22.3$ \\
\hline IV & 23.4 & $19.7-27.1$ & 29.1 & $26.2-32.0$ & 27.1 & $24.8-29.4$ \\
\hline
\end{tabular}

Note: Cl: Confidence Interval; SD: Standard Deviation.

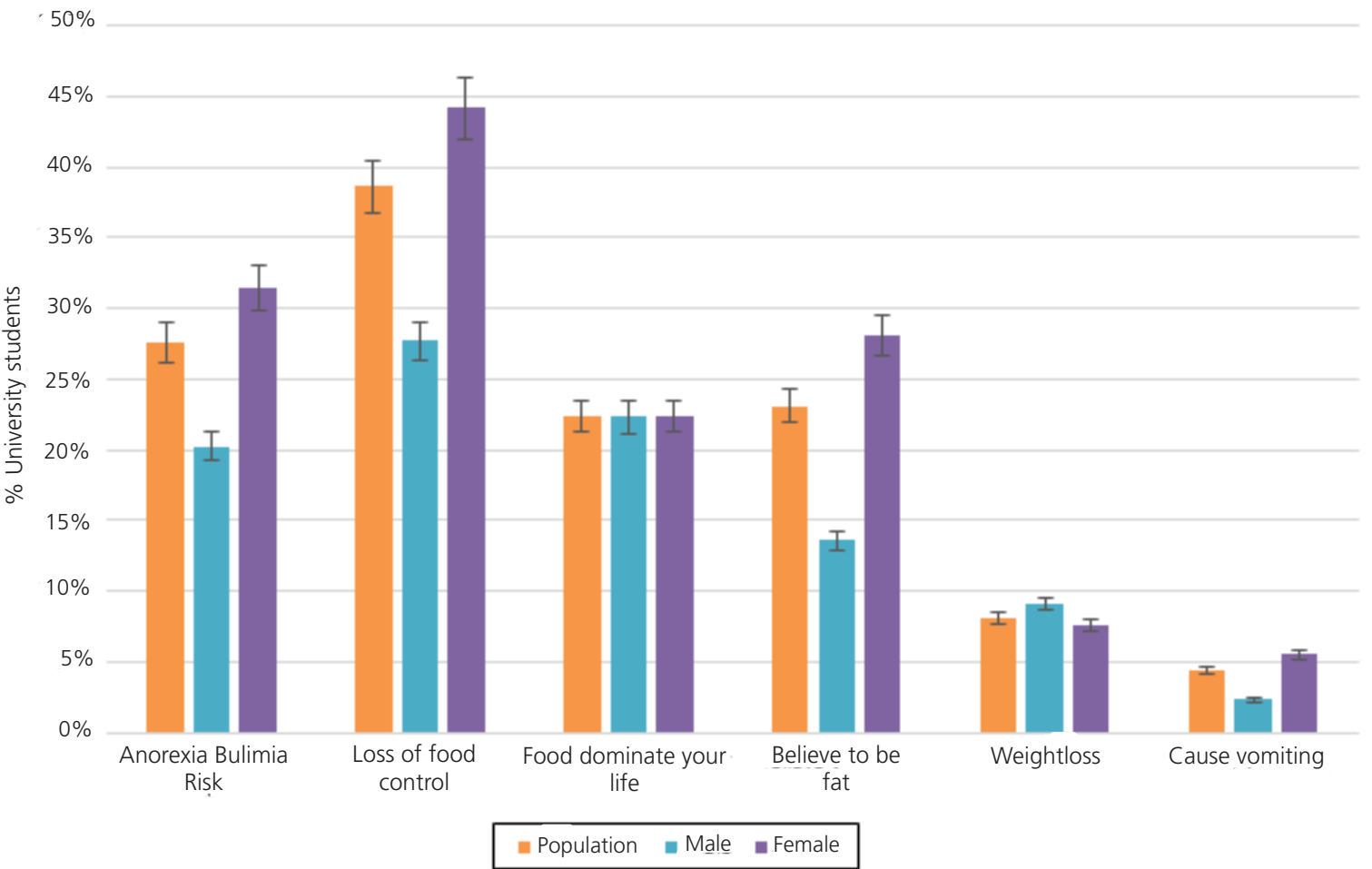

Figure 1. Prevalence of risk behaviors to anorexia or bulimia nervosa. Bogotá, Colombia, 2018. 
An increase of risk of $A B N$ was associated with female sex, second semester, daily consumption of fat and light products, disagreement with physical activity by fun, and agreement with physical activity by appearance. The risk of ABN decreased with the second level of socioeconomic status, daily consumption of cereals and protein supplements, and disagreement with physical activity by appearance (Table 2 and 3).

Table 2. Demographic factors associated with risk of anorexia or bulimia nervosa. Bogotá, Colombia, 2018.

1 of 2

\begin{tabular}{|c|c|c|c|c|c|c|c|}
\hline \multirow{2}{*}{ Variables } & \multicolumn{4}{|c|}{ ABN Risk } & \multirow{2}{*}{$p$-value } & \multicolumn{2}{|c|}{ Logistic Regression } \\
\hline & \multicolumn{2}{|c|}{ Yes $(n=427) 27.6 \%$} & \multicolumn{2}{|c|}{ No $(n=1,118) 72.4 \%$} & & OR & CI 95\% \\
\hline \multicolumn{8}{|l|}{ Age } \\
\hline Mean \pm SD & \multicolumn{2}{|c|}{$19.2 \pm 2.7$} & \multicolumn{2}{|c|}{$19.2 \pm 2.4$} & 0.399 & & \\
\hline \multirow[t]{2}{*}{ C195\% } & \multicolumn{2}{|c|}{$18.9-19.5$} & \multicolumn{2}{|c|}{$19.1-19.3$} & & & \\
\hline & $\%$ & Cl 95\% & $\%$ & Cl 95\% & & & \\
\hline Female Sex & 74.9 & $70.8-79.1$ & 62.2 & $59.3-65.0$ & $<0.001$ & 1.6 & 1.2 to 2.1 \\
\hline \multicolumn{5}{|l|}{ Provenance region } & 0.791 & & \\
\hline Bogotá & 62.1 & $57,4-66,7$ & 64.7 & $61.9-67.5$ & & & \\
\hline Bogotá surroundings & 2.3 & $0.9-3.8$ & 2.5 & $1.6-3.4$ & & & \\
\hline Eastern & 13.6 & $10.3-16.8$ & 13.6 & $11.6-15.6$ & & & \\
\hline Central & 9.8 & $7.0-12.7$ & 8.9 & 7.1-10.4 & & & \\
\hline Atlantic & 4.4 & $2.5-6.4$ & 4.4 & $3.2-5.6$ & & & \\
\hline Pacific & 3.0 & $1.4-4.7$ & 1.8 & $1.0-2.6$ & & & \\
\hline Amazon-Orinoquía & 4.7 & $2.7-6.7$ & 4.3 & $3.1-5.5$ & & & \\
\hline \multicolumn{8}{|l|}{ Socioeconomic level } \\
\hline 1 & 1.2 & $0.1-2.2$ & 2.3 & $1.4-3.2$ & 0.222 & 0.4 & 0.1 to 1.2 \\
\hline 2 & 10.5 & 7.6-13.5 & 15.0 & $12.9-17.1$ & 0.026 & 0.6 & 0.4 to 0.9 \\
\hline 3 & 41.5 & $36.8-46.1$ & 39.2 & $36.3-42.0$ & 0.414 & & \\
\hline 4 & 29.7 & $25.4-34.1$ & 28.1 & $25.4-30.7$ & 0.519 & & \\
\hline 5 & 13.6 & $10.3-16.8$ & 12.0 & $10.1-13.9$ & 0.390 & & \\
\hline 6 & 3.5 & $1.8-5.3$ & 3.4 & $2.3-4.5$ & 0.877 & & \\
\hline \multicolumn{8}{|l|}{ Civil status } \\
\hline Single & 95.1 & $93.0-97.1$ & 95.6 & $94.4-96.8$ & 0.651 & & \\
\hline With couple & 4.9 & $2.9-7.0$ & 4.4 & $3.2-5.6$ & & & \\
\hline Work, yes & 12.4 & $9.3-15.5$ & 13.9 & $11.8-15.9$ & 0.455 & & \\
\hline Couple, yes & 43.1 & $38.4-47.8$ & 39.8 & $36.9-42.7$ & 0.239 & 1.1 & 0.9 to 1.4 \\
\hline \multicolumn{8}{|l|}{ Faculty } \\
\hline Sciences & 5.2 & $3.1-7.3$ & 5.6 & $4.3-7.0$ & 0.710 & & \\
\hline Economy & 4.0 & $2.1-5.8$ & 5.4 & $4.0-6.7$ & 0.263 & & \\
\hline Politic & 4.0 & $2.1-5.8$ & 3.7 & $2.6-4.8$ & 0.772 & & \\
\hline Creation & 4.9 & $2.9-7.0$ & 6.8 & $5.3-8.3$ & 0.173 & & \\
\hline Education & 12.2 & $9.1-15.3$ & 10.1 & 8.3-11.9 & 0.239 & & \\
\hline Nursing & 7.7 & $5.2-10.3$ & 9.4 & 7.7-11.1 & 0.305 & & \\
\hline Engineering & 12.9 & $9.7-16.1$ & 18.4 & $16.2-20.7$ & 0.009 & & \\
\hline Medicine & 34.7 & $30.1-39.2$ & 29.2 & $26.6-31.9$ & 0.039 & & \\
\hline Odontology & 6.6 & $4.2-8.9$ & 5.8 & $4.4-7.2$ & 0.583 & & \\
\hline Basic course & 8.0 & $5.4-10.5$ & 5.5 & $4.2-6.9$ & 0.078 & & \\
\hline \multicolumn{8}{|l|}{ Semester } \\
\hline $1 \neq$ & 22.2 & $18.1-26.3$ & 26.4 & $23.8-29.1$ & 0.101 & 0.9 & 0.7 to 1.3 \\
\hline $2 \ddagger$ & 32.3 & $27.7-36.9$ & 25.5 & $22.8-28.1$ & 0.009 & 1.4 & 1.1 to 1.9 \\
\hline 3 & 18.9 & $15.1-22.8$ & 20.7 & $18.3-23.2$ & 0.452 & & \\
\hline 4 & 26.5 & $22.1-30.9$ & 27.4 & $24.7-30.1$ & 0.743 & & \\
\hline \multicolumn{8}{|l|}{ BMI } \\
\hline Mean \pm SD & \multicolumn{2}{|c|}{$22.8 \pm 3.3$} & \multicolumn{2}{|c|}{$21.7 \pm 3.3$} & $<0.001$ & 1.1 & 1.07 to 1.15 \\
\hline Cl 95\% & \multicolumn{2}{|c|}{$22.5-23.1$} & \multicolumn{2}{|c|}{$21.5-21.9$} & & & \\
\hline
\end{tabular}


Table 2. Demographic factors associated with risk of anorexia or bulimia nervosa. Bogotá, Colombia, 2018.

2 of 2

\begin{tabular}{|c|c|c|c|c|c|c|c|}
\hline \multirow{2}{*}{ Variables } & \multicolumn{4}{|c|}{ ABN Risk } & \multirow{2}{*}{$p$-value } & \multicolumn{2}{|c|}{ Logistic Regression } \\
\hline & \multicolumn{2}{|c|}{ Yes $(n=427) 27.6 \%$} & \multicolumn{2}{|c|}{ No $(n=1,118) 72.4 \%$} & & OR & $\mathrm{Cl} 95 \%$ \\
\hline \multicolumn{8}{|l|}{ BMI classification } \\
\hline Underweight & 5.3 & $3.1-7.5$ & 13.2 & $11.1-15.3$ & $<0.001$ & & \\
\hline Normal & 74.9 & $70.7-79.2$ & 72.5 & $69.7-75.2$ & & & \\
\hline Overweight & 16.2 & $12.6-19.8$ & 12.3 & $10.3-14.4$ & & & \\
\hline Obesity & 3.5 & $1.7-5.4$ & 2.0 & $1.1-2.8$ & & & \\
\hline
\end{tabular}

Note: BMI: Body Mass Index; CI: Confidence interval; SD: Standard Deviation.

Table 3. Food habits and physical activity associated with risk of anorexia or bulimia nervosa.

1 of 2

\begin{tabular}{|c|c|c|c|c|c|c|c|}
\hline \multirow{3}{*}{ Variables } & \multicolumn{4}{|c|}{$\mathrm{ABN}$ risk } & \multirow{3}{*}{$p$-value } & \multicolumn{2}{|c|}{ Logistic Regression } \\
\hline & \multicolumn{2}{|c|}{ Yes $(n=427) 27.6 \%$} & \multicolumn{2}{|c|}{ No $(n=1,118) 72.4 \%$} & & \multirow{2}{*}{ OR } & \multirow{2}{*}{$\mathrm{Cl} 95 \%$} \\
\hline & $\%$ & $\mathrm{Cl} 95 \%$ & $\%$ & $\mathrm{Cl} 95 \%$ & & & \\
\hline \multicolumn{8}{|l|}{ Meals: } \\
\hline Breakfast & 97.4 & $95.9-98.9$ & 98.0 & $97.2-98.8$ & 0.460 & & \\
\hline Elevens & 81.0 & $77.3-84.8$ & 84.3 & $82.2-86.5$ & 0.117 & & \\
\hline Lunch & 99.5 & $98.9-100$ & 100 & $100-100$ & 0.022 & & \\
\hline Supper & 70.5 & $66.2-74.8$ & 73.9 & 71.3-76.4 & 0.18 & & \\
\hline Dinner & 99.3 & $98.5-100$ & 99.4 & 98.9-99.8 & 0.867 & & \\
\hline Night meal & 34.7 & $30.1-39.2$ & 36.1 & 33.3-39.0 & 0.588 & & \\
\hline \multicolumn{8}{|c|}{ Daily consumption of food groups: } \\
\hline Cereals & 42.0 & $37.3-46.7$ & 46.1 & $43.2-49.0$ & 0.150 & 0.7 & 0.6 to 0.9 \\
\hline Vegetables & 21.8 & $17.7-25.9$ & 21.8 & $19.3-24.3$ & 0.990 & & \\
\hline Fruits & 42.1 & $37.4-46.8$ & 45.0 & $42.0-47.9$ & 0.317 & & \\
\hline Dairy products & 46.9 & $42.1-51.7$ & 48.5 & $45.5-51.4$ & 0.587 & & \\
\hline Meat and eggs & 42.8 & $38.1-47.5$ & 43.8 & 40.9-46.7 & 0.728 & & \\
\hline Legumes & 12.0 & 8.9-15.2 & 12.5 & $10.6-14.5$ & 0.791 & & \\
\hline Fat & 21.9 & $17.9-25.9$ & 18.0 & $15.7-20.3$ & 0.087 & 1.5 & 1.1 to 2.1 \\
\hline Sugar & 43.4 & $38.6-48.2$ & 40.8 & $37.9-43.7$ & 0.365 & & \\
\hline \multicolumn{8}{|c|}{ Daily consumption of other foods: } \\
\hline Carbonated beverages & 20.8 & $16.7-24.9$ & 18.8 & $16.3-21.2$ & 0.391 & & \\
\hline Package food & 13.7 & $10.2-17.3$ & 12.5 & $10.4-14.5$ & 0.534 & & \\
\hline Coffee. tea & 30.7 & $26.1-35.4$ & 31.1 & $28.2-34.1$ & 0.890 & & \\
\hline Light products & 18.2 & $13.7-22.6$ & 11.6 & $9.3-14.0$ & 0.006 & 1.8 & 1.1 to 2.9 \\
\hline Whole grain foods & 19.4 & $15.1-23.7$ & 14.5 & $12.1-16.9$ & 0.040 & 1.2 & 0.7 to 1.9 \\
\hline Vitamins & 17.9 & $11.9-24.0$ & 18.1 & $14.6-21.7$ & 0.957 & & \\
\hline Protein supplements & 12.0 & 5.5-18.5 & 19.7 & $15.4-24.0$ & 0.079 & 0.4 & 0.2 to 0.8 \\
\hline \multicolumn{8}{|l|}{ Physical activity level: } \\
\hline Low & 48.9 & $44.2-53.7$ & 43.6 & $40.6-46.5$ & 0.057 & 1.1 & 0.8 to 1.5 \\
\hline Medium & 20.1 & $16.3-24.0$ & 19.5 & $17.2-21.8$ & 0.777 & & \\
\hline High & 31.0 & $26.5-35.3$ & 36.9 & $34.1-39.8$ & 0.027 & 0.9 & 0.6 to 1.3 \\
\hline \multicolumn{8}{|c|}{ Motivation for doing physical activity } \\
\hline \multicolumn{8}{|l|}{ Fun } \\
\hline Agreement & 30.0 & $25.6-34.3$ & 33.6 & $30.9-36.4$ & 0.171 & 0.8 & 0.6 to 1.1 \\
\hline Disagreement & 19.2 & $15.5-23.0$ & 13.6 & 11.6-15.6 & 0.006 & 1.8 & 1.1 to 3.1 \\
\hline \multicolumn{8}{|l|}{ Appearance } \\
\hline Agreement & 47.5 & $42.8-52.3$ & 31.1 & 28.4-33.8 & $<0.001$ & 2.2 & 1.6 to 2.9 \\
\hline Disagreement & 11.2 & $8.2-14.2$ & 15.1 & $13.0-17.2$ & 0.050 & 0.6 & 0.4 to 0.9 \\
\hline
\end{tabular}


Table 3. Food habits and physical activity associated with risk of anorexia or bulimia nervosa.

2 of 2

\begin{tabular}{|c|c|c|c|c|c|c|c|}
\hline \multirow{3}{*}{ Variables } & \multicolumn{4}{|c|}{$\mathrm{ABN}$ risk } & \multirow{3}{*}{$p$-value } & \multicolumn{2}{|c|}{ Logistic Regression } \\
\hline & \multicolumn{2}{|c|}{ Yes $(n=427) 27.6 \%$} & \multicolumn{2}{|c|}{ No $(n=1,118) 72.4 \%$} & & \multirow{2}{*}{ OR } & \multirow{2}{*}{ CI 95\% } \\
\hline & $\%$ & $\mathrm{Cl} 95 \%$ & $\%$ & $\mathrm{Cl} 95 \%$ & & & \\
\hline \multicolumn{8}{|l|}{ Health } \\
\hline Agreement & 47.3 & $42.6-52.1$ & 47.9 & $45.0-50.9$ & 0.823 & & \\
\hline Disagreement & 11.9 & 8.9-15.3 & 8.6 & $6.9-10.2$ & 0.044 & 1.6 & 0.9 to 2.9 \\
\hline \multicolumn{8}{|l|}{ Competition } \\
\hline Agreement & 31.6 & $27.2-36.0$ & 34.5 & $31.7-37.3$ & 0.279 & & \\
\hline Disagreement & 18.7 & $15.0-22.5$ & 15.7 & $13.5-17.8$ & 0.144 & 0.9 & 0.5 to 1.4 \\
\hline \multicolumn{8}{|l|}{ Socialize } \\
\hline Agreement & 6.8 & $4.4-9.2$ & 6.1 & $4.7-7.5$ & 0.607 & & \\
\hline Disagreement & 38.4 & $33.8-43.0$ & 39.4 & $36.5-42.2$ & 0.733 & & \\
\hline
\end{tabular}

Note: ABN Anorexia or Bulimia Nervosa; Cl: Confidence interval; OR: Odds Ratio.

\section{DISCUSSION}

This is the first report about the risk of $A B N$ in university students of multiples academics programs; these findings include previously risk factors (sex and physical exercise by appearance) and highlight eating behaviors (intake of cereals, fat, protein supplements, and light products).

Respect to other studies that used SCOFF, the prevalence are different, for example, $20.7 \%$ in France, $19.5 \%$ in Spain, 39.5\% in Peru, $16.0 \%$ in The United States, $39.7 \%$ in Greece, and $14,2 \%$ to $21.2 \%$ in Colombia $[3,9]$. These variabilities are generated by differences in average age, the inclusion of some academic programs, and the fluctuating presence of females. However, these prevalence are a call of the presence of risk of $A B N$ in university students around the world and could be an indirect manifestation of the variability of the disease spectrum generated by population dynamics, geographical area, and the type of university, so multicenter studies in other universities and countries are required to increase the plausibility of the findings.

This research describes that "lost control over how much you eat" is the risk behavior to anorexia or bulimia nervosa more prevalent, while "make yourself sick because you feel uncomfortably full" is the less prevalent. This discovery agrees with results from France and India, however, reports usually do not describe this information, hence avoiding the possibility to identify risk behaviors to anorexia or bulimia nervosa in university students $[3,10]$. Due to these limitations, future research in the field of risk of ABN should improve plausibility and consistency of results, including more universities and using two or more instruments to screening the risk of $A B N$.

It was found that female sex is associated with the risk of $A B N$, which was similar to that found in the study by Deossa et al. [12] in Antioquia (p<0.05), Tavolacci et al. [3] in France (OR 3 CI95\% 2.3-3.9) and Kronfol et al. [6] in USA-Arabia (OR 2.5 CI95\% 1.4 to 4.5). As seen, regardless of the region or the statistical method, being of the female sex is linked to the risk of $A B N$, however, according to the previous authors, it is not the fact of being a woman that generates the risk, it is the social environment that puts more pressure on women to achieve conventions of beauty and acceptance.

The risk of $A B N$ increases with the daily consumption of Light products and Fat, at the same time, the risk decreases with the daily consumption of cereals and protein supplements. These associations of daily 
consumption of some groups in university students could be explained by the control in the consumption of these food groups by women in their need to reduce or control their weight, due to the fact that weight gain is somewhat undesirable for the person with anorexia or bulimia nervosa [4]. Furthermore, some level of information bias can influence the association, for example, reports of fat consumption can be overestimated due to the perception of fat intake and gaining weight. Therefore, future research should measure diet intake with direct methods.

Regarding physical activity the risk of $A B N$ increases with the disagreement of physical activity for fun and agreement for appearance, at the same time, disagreement of exercise for appearance declines the risk. These discoveries represent the relevance of PA to the body image in the anorexia or bulimia nervosa, taking the exercise as a way to obtain or satisfy their impulse to improve the body image, in other words, the exercise allows to improve the appearance and therefore will be against practicing it for fun [16].

This study has many strengths, for example, the sample size was fourth times bigger than the initial estimation, the inclusion of 25 undergraduate programs, some characteristics of the population were represented in the sample (semesters and age), the participation of students from various regions of the country, heterogeneity of socioeconomic strata, the evaluation of food intake, and the measure of physical activity and motive to do physical activity.

However, some details can limit the external validity and extrapolation of the results. First, this study involved university students from one university and until the second year of the academic programs; hence, coming research could involve universities from several places and students of all academic years. Second, the self-report of food intake, PA, and body measures could introduce an unknown information bias in the association between these variables and the risk of $A B N$; although the research involved validated tools, future studies should include direct or quantitative measures, like 24 hours intake, consumer diaries, pedometers, accelerometers, and measures of body composition by impedance or anthropometry.

Finally, no study has fully described the panorama of factors related to the risk of ABN in university students, studying mainly psychological variables (coping and depression), psychological background, and attitudes towards body image $[12,18]$. This research contributes to the understanding of the phenomenon, adding that agreeing to do PA by appearance, being against doing PA for fun, and eating cereals and fats are also related to the risk of $A B N$. Therefore, it is encouraged that the next research integrally covers the psychological, biological, demographic, geographical, cultural, and food aspects to fully describe the factors related to risk of $A B N$ in undergraduate students.

\section{CONCLUSION}

A high prevalence of risk of anorexia and bulimia nervosa was found; the risk behaviors more prevalent were "believe yourself to be Fat", "say that Food dominates your life", and "worry about lost Control over how much you eat". The risk of anorexia and bulimia nervosa increase with female sex, second semester, daily consumption of fat food group, daily consumption of light food products, disagreement in doing physical activity by fun, and agreement of doing physical activity by appearance. At the same time, the risk decreased with daily consumption of cereals, protein supplements, and disagreement in doing physical activity by appearance. Upcoming research should cover multiple universities, variables, and instruments, which will increase the comprehensive understanding of the phenomenon and provide support for the development of health promotion actions. 


\section{REFERENCES}

1. Spillebout A, Dechelotte P, Ladner J, Tavolacci MP. Mental health among university students with eating disorders and irritable bowel syndrome in France. Rev Epidemiol Sante Publique. 2019;67(5):295-301. https://doi.org/10.1016/j. respe.2019.04.056

2. Garrido-Miguel M, Torres-Costoso A, Martínez-Andrés M, Notario-Pacheco B, Díez-Fernández A, Álvarez-Bueno $C$, et al. The risk of eating disorders and bone health in young adults: the mediating role of body composition and fitness. Eat Weight Disord. 2019;24(6):1145-54. https://doi.org/10.1007/s40519-017-0458-x

3. Tavolacci MP, Grigioni S, Richard L, Meyrignac G, Déchelotte P, Ladner J. Eating disorders and associated health risks among university students. J Nutr Educ Behav. 2015;47(5):412-20.e1. https://doi.org/10.1016/j.jneb.2015.06.009

4. Lichtenstein MB, Griffiths MD, Hemmingsen SD, Støving RK. Exercise addiction in adolescents and emerging adults: validation of a youth version of the Exercise Addiction Inventory. J Behav Addict. 2018;7(1):117-25. https://doi. org/10.1556/2006.7.2018.01

5. Romo L, Ladner J, Kotbagi G, Morvan Y, Saleh D, Tavolacci MP, et al. Attention-deficit hyperactivity disorder and addictions (substance and behavioral): prevalence and characteristics in a multicenter study in France. J Behav Addict. 2018;7(3):743-51. https://doi.org/10.1556/2006.7.2018.58

6. Kronfol Z, Khalifa B, Khoury B, Omar O, Daouk S, Witt JP, et al. Selected psychiatric problems among college students in two Arab countries: comparison with the USA. Bmc Psychiatr. 2018;18(1):147-55. https://doi.org/10.1186/ s12888-018-1718-7

7. Wan Wahida, Wan Mohd Zohdi, Lai PSM, Abdul Hadi H. Validity and reliability of the english version of the sick, control, one stone, fat, food (SCOFF) in Malaysia. Clin Nutr ESPEN 2017;18:55-58. https://doi.org/10.1016/j. clnesp.2017.02.001

8. Sanchez-Armass O, Raffaelli M, Andrade F, Wiley A, Noyola A, Arguelles A, et al. Validation of the SCOFF questionnaire for screening of eating disorders among Mexican university students. Eat Weight Disord. 2017;22(1):153-60. https:// doi.org/10.1007/s40519-016-0259-7

9. Plasencia Dueñas EA. Variabilidad de frecuencias de trastornos de la conducta alimentaria (TCA): ¿problema de población o de instrumento? Nutr Hosp. 2015;31(6):2779-81. https://doi.org/10.3305/nh.2015.31.6.8849

10. Vijayalakshmi P, Thimmaiah R, Reddy S, Kathyayani BV, Gandhi S, Bada S. Gender differences in body mass index, body weight perception, weight satisfaction, disordered eating and weight control strategies among Indian medical and nursing undergraduates. Invest Educ Enferm. 2017;35(3):276-84. https://doi.org/10.17533/udea.iee.v35n3a04

11. Ministerio de Salud (Colombia). Encuesta Nacional de Salud Mental 2015. Bogota: Ministerio; 2015.

12. Deossa R, Restrepo L, Velasquez J. Actitudes y comportamientos de riesgo para trastornos de la conducta alimentaria en jóvenes universitarios, Colombia. Hacia Promoc Salud. 2015;20(1):67-82. https://doi.org/10.17151/ hpsal.2015.20.1.5

13. Kutz AM, Marsh AG, Gunderson CG, Maguen S, Masheb RM. Eating disorder screening: a systematic review and meta-analysis of diagnostic test characteristics of the SCOFF. J Gen Intern Med. 2019;35(3):885-93. https://doi. org/10.1007/s11606-019-05478-6

14. Herrán OF, Bermúdez JN, Zea MP. Cambios alimentarios en Colombia: resultados de dos encuestas nacionales de nutrición, 2010-2015. Salud. 2020;52(1):21-31. https://doi.org/10.18273/revsal.v52n1-2020004

15. International Physical Activity Questionnaire. Guidelines for data processing and analysis of the International Physical Activity Questionnaire (IPAQ). Short and long forms. [cited: 2018 April 1]. Available from: https://sites.google.com/ site/theipaq/scoring-protocol

16. Rodríguez Castellanos FA, Valencia SC, Gaitán Guzmán EM, González Rodríguez SA, León Díaz JD. Hábitos saludables, motivos y barreras en la realización de actividad física en estudiantes universitarios. Cuerpo, Cultura y Movimiento 2017;7(1):81-102. https://doi.org/10.15332/s2248-4418.2017.0001.05

17. Díaz-Muñoz GA. Caracterización de los hábitos alimentarios y nivel de actividad física en estudiantes universitarios. Revista Salud Bosque 2018;8(1):8-19. https://doi.org/10.18270/rsb.v8i1.2371

18. Ureña-Molina MDP, Pacheco-Milian M, Rondón-Ortega MJ. Conductas alimentarias de riesgo y su relación con la imagen corporal en estudiantes de enfermería. Rev Cienc Cuidad. 2015;12(2):57-71. https://doi.org/10.224 $63 / 17949831.509$ 